\title{
THE AVAILABILITY AND USE OF MEDIA INFORMATION SOURCES IN RURAL AREAS
}

\author{
Ewa Jaska ${ }^{1}$, Phd; Agnieszka Werenowska ${ }^{2}$, Phd \\ 1,2 Faculty of Economics, Warsaw University of Life Sciences, Poland
}

\begin{abstract}
This paper explores the availability and use of media information sources in rural areas. The theoretical part compares the content delivered by traditional media to the one delivered by new media. The empirical part provides analysis of data from years 2013 - 2017 provided by the Central Statistical Office (GUS), which show changes in the availability and use of information and communication technologies (ICT) in Poland by household, with particular focus on rural areas. Additionally, the paper presents the findings of the study Polish Rural Areas and Agriculture (Polska Wies i Rolnictwo) carried out for the Ministry of Agriculture and Rural Development and subordinate institutions, including: Agency for Restructuring and Modernization of Agriculture (ARiMR), Agricultural Market Agency (ARR), Rural Property Agency (ANR) and Agricultural Social Insurance Fund (KRUS). The study was conducted in years 2014-2016 and involved a survey research of rural residents, including farmers. Part of the study focused on media information sources. The paper uses a descriptive method, and detailed data is presented in a tabular format. The analysis demonstrates that there is less availability and use of new ICT in rural areas compared to Poland's average, but these differences are gradually decreasing. In particular, a high growth rate was recorded in the category of household access to broadband Internet, the number of farmers and rural residents regularly using the Internet increased and so did number of rural residents using social networking sites. The awareness of the role of competences necessary to use new technologies is also growing. However, rural residents and farmers are still less likely to use e-government services. Farmers still consider television to be the main source of information on available EU funds for the development of agriculture and rural areas, although they also hold the opinion that the Internet should be used more widely.
\end{abstract}

Key words: information, media, new information and communication technologies, rural areas.

Jel code: 033

\section{Introduction}

Information has become one of the most important commodities today and that is why access to it as well as appropriate use of relevant information sources, including media, is so important. This applies to all areas of social and economic life, including agriculture and rural residents. Thanks to modern technology, information transfer can take place virtually anywhere in the world. The medium that allows the fastest information transfer is undoubtedly the Internet and this particular means of communication has clearly inspired changes in the style of media use in recent years. Information has become the main attribute of information society and it has developed as a result of the use of new information and communication technologies (ICT). The information availability itself is insufficient as the incoming messages need to be received, processed and analysed. Therefore, it is necessary to be able to use new technological solutions in the field of information management.

The aim of this paper is to present the availability and use of media information sources in ruralareas and the characteristics of the content delivered by traditional and new media. ICT are still less available and used in rural areas compared to Poland's average, but these differences are gradually decreasing. Farmers still regard television as the main source of information on EU funds, although they also suggest that the Internet should be used more widely in this area.

Therefore, the data from 2013 - 2017 provided by the Central Statistical Office (hereafter referred to as GUS) were analysed to show changes in the availability and use of ICT in Poland by household, with particular focus on rural areas. In Poland, the monitoring of the use of ICT in households was implemented in 2004. The used methodology was correlated with counterpart 
research conducted in the European Union. The research is carried out by direct and telephone interview. In 2014, changes were made to the methodology used until 2013 (the new method included farms with family members aged $12-15$, previously - 16-74 year olds, and the number of surveyed households increased from 8100 to 16200 ) (Central Statistical Office, 2017).

This paper also analyses the results of the study Polish Rural Areas and Agriculture (Polska wies i rolnictwo) carried out in 2014-2016 and commissioned by the Ministry of Agriculture and Rural Development and subordinate institutions (Agency for Restructuring and Modernization of Agriculture, Rural Property Agency, Agricultural Market Agency, Agricultural Social Insurance Fund) and carried out by a consortium of Grupa BST and EU-Consult. The study involved personal interviews of two types: where the interviewer inputs data on paper (PAPI) and where data are input directly to a computer (CAPI). In 2016, the study involved 1.563 residents of rural areas from all over Poland, including 902 farmers. This opinion poll serves the purpose to monitor socio-economic changes taking place in rural areas, evaluate the activities of institutions working for the development of agriculture and rural areas as well as monitor the availability and use of media information sources (Ministry of Agriculture and Rural Development, 2017).

The study uses secondary sources and a descriptive and analytical approach. Detailed data are presented in a tabular format.

\section{Characteristics of content delivered by traditional media and new media}

Information society relies on media as the key information source, and new media are becoming increasingly important. Media are broadly perceived as a source of information and entertainment, although initially the idea of media creation was guided by the purpose of using modern technology to generate profit, and media expansion was driven by advertising (Sorlin P., 2001).

Since the 20th century, media have been developing very fast and expanding their reach, starting from local press, through national press, to the rise of electronic media, i.e. the radio, television and the Internet. The reach and impact of media have had the effect of making us all, to some extent, dependent on access to information they provided. The on-going transformations in this area have been described by three basic media conventions: broadcasting, narrowcasting and ego-casting (Sosnowska J., 2014). In the first convention, content is delivered to the broader public at-large, which meant that the same message was sent to diverse recipients, while in the case of narrowcasting a more profiled message, converging with the expectations of recipients, is aimed at specific segments of the audience. Nowadays the phenomenon of ego-casting is proliferating where individual recipient selects and focuses only on content that they find interesting. Such extremely personalized reception becomes the viewer's limitation because the recipient does not take advantage of the content, which in their opinion is uninteresting (Szpunar M., 2014).

Media have achieved a very high degree of flexibility. All kinds of thematic press, radio and TV channels have been tailored to specific recipients' needs. Therefore, everyone, independently of their interests, can find information or entertainment that will appeal to them. What is more, media mold our attitudes and influence behaviour towards specific situations. Usually, the audience does not realize that. Passive recipients of media sent messages submit to what is conveyed to them. This is, among other things, the result of the characteristics of media messages themselves, which are designed to attract the attention of as many people as possible. Consequently, various entities 
of social and economic life use media not only to provide information but also to influence the attitudes and behaviour of the recipients (Goban-Klas T., 2004).

The aim of media content, in particular the advertising message, is to reach the recipient, be remembered and finally generate the expected reaction of the potential client. Depending on the content of the message, feedback from the recipient may take a long time, may be very quick or may never reach the sender. Feedback, and frequent problems with receiving it, is one of the main problems faced by message senders who use traditional media (Golka M., 2008). In contrast, new media users are significantly more active and do not present exclusively passive attitudes. Users of new means of social communication participate in creating information and opinions. Through easy access to the Internet, recipients become co-creators of the media content.

M. Jezinski lists four dimensions of new media interactivity. The first one, spatial, is defined as establishing bilateral or multilateral communication. The second, the time dimension, is the ability to communicate in any place and time of convenience. The third is the behavioural dimension, i.e. the ability to exchange roles, between the recipient and the sender and exercise control over what happens during the interaction. The fourth - intellectual dimension - is defined as the ability to understand the meanings and contexts of the interaction (Jezinski M., 2009).

When traditional and new media are compared, nine communication features need to be considered: speed, reach, storage capacity, accuracy, selectivity, interactivity, stimuli richness, complexity and privacy protection (Van Dijk J., 2010). Both new media and some of traditional media (TV, radio) have a similar speed of contact around the world. Using a telephone or e-mail, we are able to contact instantly any person anywhere in the world. Reach has both geographical and social dimension. In the case of new media, reach is very large, because all countries are connected to integrated telecommunications networks enabling data exchange via telephone lines and the Internet. In turn, storage capacity in the case of new media is much larger than in traditional media. You can store almost unlimited amount of information in digital memory. Accuracy of information is a category that also distinguishes new media, because messages sent through new media are more precise compared to often ambiguous messages conveyed through e.g. telephone lines. Selectivity of messages and recipients is a crucial communication feature. In new media, recipient groups are precisely defined and it is through them that specific people can be contacted. A very special feature of new media is their interactivity; however, the exchange does not reach the level of a direct conversation, because we do not send emotions and non-verbal cues. Similarly, when it comes to the richness of stimuli, new media are unable to provide the same amount of stimuli as a real experience, and that is why, for example, online shopping cannot live up to direct shopping in a store. Also the complexity of new media is still rather low, it is difficult to make decisions or negotiate over a computer network. Privacy protection in the case of new media is either difficult, or even entirely impossible. The radio, press and television can be used anonymously, while on the Internet users' profiles are created and all their activities are recorded.

Interactive new media have played a crucial role in stimulating changes in the accessibility and reception of media content. The main manifestations of these changes include:

- recipients continuously flow between various broadcasts, channels or media, (audience flows);

- audience is changing in terms of size, intensity of contact and composition, (fluid audience), and thus the auditorium is increasingly diversified and fragmented; 
- content is more accessible due to the greater number of networks, i.e.: terrestrial TV, cable TV, satellite TV , Internet TV, mobile TV, mobile telephony, the Internet and wider use of multifunction devices (computer, tablet, mobile phone);

- time-shifted viewing has become an alternative to broadcast transmission - non-linear use of recorded content or on-demand services are increasingly popular;

- multi-screening, the phenomenon of simultaneous use of several electronic devices to receive media content, is on the rise.

The above comparison demonstrates that new media offer much more communication possibilities than traditional media. However, despite many unquestionable advantages, new media have also their drawbacks and limitations. The most important is definitely the lack of privacy and anonymity on the Internet, as well as the enormous scale of communicated content often leading to information noise and the absolute necessity to select the content reaching the recipient.

\section{The use of information and communication technologies in households (ICT) in rural areas - research results}

In 2017, nearly $82 \%$ of households in Poland had access to a computer, and in rural areas it was $79 \%$ (Table 1). In the same year, 22.0 million people in Poland used a computer regularly, which is an increase by 10.4 percentage points compared to 2013. While the total for Poland was $71.2 \%$ of regularly computer users, in rural areas it was $64.8 \%$.

Table 1

Household access to a computer and the Internet in total and in rural areas in years $2013-2017$ (in \%)

\begin{tabular}{|l|l|l|l|l|l|l|}
\hline \multicolumn{1}{|c|}{ Specification } & & $\mathbf{2 0 1 3}$ & $\mathbf{2 0 1 4}$ & $\mathbf{2 0 1 5}$ & $\mathbf{2 0 1 6}$ & $\mathbf{2 0 1 7}$ \\
\hline \multirow{2}{*}{ Households possessing a computer } & Rural areas & 71.7 & 73.6 & 75.0 & 77.0 & 78.8 \\
\cline { 2 - 6 } & Total & 74.7 & 77.1 & 77.9 & 80.1 & 81.8 \\
\hline \multirow{2}{*}{ Regular computer users } & Rural areas & 51.4 & 54.8 & 56.8 & 62.3 & 64.8 \\
\cline { 2 - 6 } & Total & 60.8 & 63.5 & 64.8 & 69.1 & 71.2 \\
\hline \multirow{2}{*}{ Households with Internet access } & Rural areas & 67.8 & 71.5 & 72.0 & 77.8 & 78.6 \\
\cline { 2 - 6 } & Total & 71.9 & 74.8 & 75.8 & 80.4 & 81.9 \\
\hline \multirow{2}{*}{ Households with broadband Internet access } & Rural areas & 63.0 & 66.7 & 64.7 & 71.3 & 74.1 \\
\cline { 2 - 6 } & Total & 68.8 & 71.1 & 71.0 & 75.7 & 77.6 \\
\hline
\end{tabular}

Source: authors' elaboration based on: Information Society in Poland. Statistics from the years 2013 - 2017. Central Statistical Office (GUS) Statistical Office in Szczecin. Information and Statistics, Warszawa - Szczecin 2017, pp. 108-120.

As for the access to the Internet, in 2017, $78.6 \%$ of households in rural areas had Internet access compared to $81.9 \%$ of households nationwide. In comparison to 2013 , the biggest increase in the Internet access rate was recorded in rural areas and in areas with low urbanization (respectively 10.8 and 11.6 percentage points). Also access to broadband Internet needs to be mentioned here. Rural households were much less likely to have broadband Internet access than households in cities. In 2017, this proportion was $74.1 \%$ in rural areas, and $81.5 \%$ in big cities. Compared to 2013, the biggest increase in the proportion was recorded in rural areas (11.1 percentage points), while in smaller and big cities, it was respectively 9.2 and 6.4 percentage points.

It is worth noting that the biggest growth in the proportion of regular Internet users compared to 2013 was recorded in the group of farmers (20.4 percentage points). Rural areas also recorded the biggest increase (by 14.2 percentage points) in the proportion of regular Internet users in the 
analysed period. In the population of pupils and students, this increase was insignificant. Obviously, the indicator was already high at the beginning of the analysed period.

The most-often-declared reason for not having Internet access at home is still the lack of such a need. In comparison to 2016, this indicator has decreased by 3 percentage points and in 2017 it was $67.6 \%$ of households with no access to the Internet. It turns out that this reason was most frequently declared by the residents of smaller cities, less often by the residents of rural areas, and the least frequently by the residents of big cities. However, the disproportions between the aforementioned groups are not big and in the case of rural areas it was $67.1 \%$ of responses, and in big cities - $65 \%$. The second declared reason was the lack of adequate skills (54.2\%), although in recent years respondents have been more likely to indicate Internet aversion as the reason for not having access to it at home. It is therefore important to recognize the crucial role of competences to use new technologies to one's benefit.

Internet communication is the most popular among pupils and students and residents of big cities. In 2017, the most popular form of Internet communication was electronic mail and social networking sites. The same tendency was observed in years $2013-2017$, both nationwide and in rural areas. The highest growth dynamics was recorded in the group of rural residents using social networking sites, and in comparison to 2013 it increased by 13.6 percentage points. Sending and receiving e-mail is still the most popular form of Internet use. In the analysed period, an increase in e-mail use of 9.2 percentage points was recorded in rural areas and 8.3 percentage points nationwide (Table 2).

Table 2

Use of online communications services in the past three months (in \%)

\begin{tabular}{|l|l|c|c|c|c|c|}
\hline Online communications services & & $\mathbf{2 0 1 3}$ & $\mathbf{2 0 1 4}$ & $\mathbf{2 0 1 5}$ & $\mathbf{2 0 1 6}$ & $\mathbf{2 0 1 7}$ \\
\hline \multirow{2}{*}{ Instant messaging } & Total & 21.3 & 16.4 & 8.8 & 20.6 & 29.7 \\
\cline { 2 - 7 } & Rural areas & 17.7 & 14.2 & 7.3 & 16.6 & 26.1 \\
\hline \multirow{2}{*}{ Using social networking sites } & Total & 35.3 & 36.8 & 41.4 & 44.2 & 48.0 \\
\cline { 2 - 7 } & Rural areas & 30.9 & 32.9 & 37.8 & 40.3 & 44.5 \\
\hline \multirow{2}{*}{ Telephoning via the Internet } & Total & 24.1 & 27.5 & 27.6 & 28.2 & 31.7 \\
\cline { 2 - 7 } & Rural areas & 18.6 & 21.4 & 21.1 & 22.0 & 26.3 \\
\hline \multirow{2}{*}{ Sending and receiving e-mail } & Total & 51.5 & 52.9 & 54.0 & 57.8 & 59.8 \\
\cline { 2 - 7 } & Rural areas & 41.3 & 43.6 & 42.8 & 48.3 & 50.5 \\
\hline
\end{tabular}

Source: authors' elaboration based on: Information Society in Poland. Statistics from the years 2013 - 2017. Central Statistical Office (GUS) Statistical Office in Szczecin. Information and Statistics, Warszawa Szczecin, pp. $134-135$.

In 2017, the survey was supplemented by a new question concerning the respondents' participation in sharing economy - using websites or applications that act as intermediaries between private persons offering accommodation or transport services and private individuals who want to use these services. The study showed that it is more popular to use shared accommodation than transport ( $15.0 \%$ and $6.2 \%$, respectively). The websites or applications in the field of sharing economy are more often used by younger people with higher education and self-employed (Table 3). In the groups of rural residents and farmers, these rates are the lowest, but it undoubtedly results from the nature of the profession and needs in this area. 
Using websites or applications for sharing economy in 2017 ( $\%$ of total individuals in a group)

\begin{tabular}{|l|c|c|}
\hline \multicolumn{1}{|c|}{ Specification } & $\begin{array}{c}\text { Arranging } \\
\text { accommodation }\end{array}$ & $\begin{array}{c}\text { Arranging } \\
\text { transport } \\
\text { services }\end{array}$ \\
\hline Total & $\mathbf{1 5 . 0}$ & $\mathbf{6 . 2}$ \\
\hline \multicolumn{2}{|c|}{ Employment situation } & 14.6 \\
\hline Students & 20.4 & 11.8 \\
\hline Persons employed & 21.5 & 7.6 \\
\hline Employees & 29.6 & 7.9 \\
\hline Self-employed & 1.9 & 11.3 \\
\hline Farmers & 6.7 & 1.3 \\
\hline Unemployed & 5.0 & 3.3 \\
\hline Retired or other not in the labor force & & 1.5 \\
\hline \multicolumn{1}{|c|}{ Domicile } & 26.8 & 11.2 \\
\hline Big cities & 13.9 & 5.1 \\
\hline Small cities & 7.6 & 3.4 \\
\hline Rural areas & & \\
\hline
\end{tabular}

Source: authors' elaboration based on: Information Society in Poland. Statistics from the years 2013 - 2017. Central Statistical Office (GUS) Statistical Office in Szczecin. Information and Statistics, Warszawa - Szczecin 2017 , p. 137.

The Internet was also used for contacts with public administration bodies. In 2017, the respondents showed increased interest in downloading official forms and sending them. In comparison to 2013, the percentage of people using the service of sending completed forms has almost doubled. In previous years, the most popular form of using e-government services was searching for information on public administration websites, also in rural areas. Residents of big cities were more likely to use E-government services than the residents of rural areas. In the case of downloading forms or sending completed ones, the two groups differed by approx. 20 percentage points.

\section{The media sources of information about rural development and agriculture preferred by Polish farmers - research results}

The analysis of the reports Polish Rural Areas and Agriculture from years 2014-2016 demonstrates that the main source of information on available EU funds for the development of agriculture and rural areas is television. In 2016, this was the opinion of $48 \%$ of farmers participating in the study, similarly to preceding years (Table 4). In the survey, respondents were asked which TV station provided the aforementioned information, and almost half of the farmers indicated Channel 1 of TVPS.A. For rural residents, television is also the main source of information on certificates confirming the quality of foodstuffs and agricultural products ( $55 \%$ of respondents). Information on this subject was also obtained from press articles (36\%), family and friends ( $35 \%$ ) and websites ( $35 \%)$. Television remained the key information source for over half of the respondents regardless of their age (Ministry of Agriculture and Rural Development, 2017).

It is worth noting that the number of farmers obtaining information from the radio decreased from $21 \%$ in 2014 to $13 \%$ in 2016. Over a quarter of radio listeners indicated Polish Radio 1 as the main information source. As for the Internet, the role of this information source increased in the analysed period of time. The website most frequently visited by farmers (24\%) was arimir.gov.pl run by the Agency for Restructuring and Modernization of Agriculture. The farmers 
were also asked to what extent they found the information on Rural Development Programme 2014-2020 posted on the Internet (www.minrol.gov.pl, www.arimr.gov.pl, www.arr.gov.pl) understandable. The best understanding of this information was declared by farmers who were the beneficiaries of direct payments, $8 \%$ of them answered that this information is 'definitely understandable' and $45 \%$ - 'rather understandable'.

Table 4

\begin{abstract}
Main media sources of information about changes taking place in rural areas and agriculture as well as the possibility of obtaining EU funds in 2014-2016 ( $\%$ of respondents in the group of farmers)
\end{abstract}

\begin{tabular}{|l|c|c|c|}
\hline \multicolumn{1}{|c|}{ Information source } & $\begin{array}{c}\mathbf{2 0 1 4} \\
\mathbf{N = 8 6 6}\end{array}$ & $\begin{array}{c}\mathbf{2 0 1 5} \\
\mathbf{N = 6 8 2}\end{array}$ & $\begin{array}{c}\mathbf{2 0 1 6} \\
\mathbf{N = 7 7 2}\end{array}$ \\
\hline Television & $45 \%$ & $49 \%$ & $48 \%$ \\
\hline Radio & $21 \%$ & $15 \%$ & $13 \%$ \\
\hline Internet & $18 \%$ & $27 \%$ & $30 \%$ \\
\hline Daily press & $13 \%$ & $20 \%$ & $13 \%$ \\
\hline Specialized trade press & $11 \%$ & $19 \%$ & $20 \%$ \\
\hline $\begin{array}{l}\text { Publications of institutions } \\
\text { acting for the development } \\
\text { of rural areas and } \\
\text { agriculture }\end{array}$ & $6 \%$ & $9 \%$ & $24 \%$ \\
\hline
\end{tabular}

Source: authors' elaboration based on the report Polish Rural Areas and Agriculture (Polska wies i rolnictwo) 2014-2016, http://www.minrol.gov.pl/opracowania-ekspertyzy-publikacje (Retrieved on 7 Jan 2018)

In the category of daily press, the respondents most frequently looked for information in regional newspapers and national titles: Gazeta Wyborcza and Dziennik Polski. In the category of specialized trade press, it was Poradnik Rolniczy and Farmer. However, daily press, just like radio, was mentioned in 2016 only by $13 \%$ of the surveyed farmers. When analysing the significance of particular media information sources, it is worth noting that farmers showed increased interest in publications of institutions acting for the development of rural areas and agriculture.

Another two important information sources included: ads placed on notice boards in commune (gmina) offices or county (powiat) offices as well as neighbours, family and friends (in both cases more than $40 \%$ of respondents indicated these sources).

The respondents were also asked for suggestions regarding improvements and changes in the scope of activities promoting Rural Development Programme 2014-2020 (RDP). In the group of RDP beneficiaries, the majority of respondents (53\%) suggested wider use of the Internet and other forms of electronic communication as the most urgent change in this area. Half of the surveyed beneficiaries of the RDP were of the opinion that it is also necessary to provide more information and broadcasts on the radio and television, and $34 \%$ were in favour of the press. The respondents also suggested other forms of disseminating useful information such as meetings (46\%), extended activities of agricultural advisors and the need to simplify the language of provided information. The latter was indicated by $26 \%$ of RDP beneficiaries, notably, it was the group who declared the best understanding of information compared to other respondents

\title{
Conclusion
}

1) In Poland, residents of rural areas, including farmers, are still categorized as the social group with lesser access to modern information sources, although in recent years this gap has been decreasing. The data presented in this paper show that: 
- differences in the proportion of households equipped with a computer and access to the Internet are diminishing - the most significant increase was recorded in the access to broadband Internet;

- the number of regular internet users increased among farmers and rural residents;

- the highest growth rate in the proportion of people using social networking sites was recorded in the group of rural residents;

- rural residents are less likely to use e-government services;

- the awareness of the role of competences to use new technologies increases;

- farmers still consider television the main source of information on EU funds for the development of agriculture and rural areas, although they also suggest that the Internet should be used more widely.

2) In order to close the still existing gap, actions should be taken to increase social awareness of the role that information technologies play in the modern world. That is why initiatives enabling continuous education of people in this field are so important, both in the perspective of an individual and social groups. The amount of knowledge to which we have access, thanks to widespread information, with appropriate use, can bring numerous benefits in the form of better standard of living and chances to catch up with the economic level of more developed regions both on the national and global scale

\section{Bibliography}

1. Goban-Klas, T. (2004). Media i komunikowanie masowe: teorie i analizy prasy, radia, telewizji i Internetu (Media and mass communication: theories and analyzes of the press, radio, television and the Internet.). Warszawa: PWN. p. 325.

2. Golka, M. (2008). Bariery w komunikowaniu i spoleczenstwo (dez)informacyjne (Barriers in communication and (dis)information society). Warszawa: PWN. pp. 55-60.

3. Information Society in Poland. Statistics from the years $2013-2017$. Central Statistical Office (GUS) Statistical Office in Szczecin. Information and Statistics, Warszawa 2017.

4. Jezinski M., Nowe media a media tradycyjne: prasa, reklama, internet (New media and traditional media: press, advertising, internet), Wydawnictwo Adam Marszałek, Torun 2009, pp. 308-310.

5. Ministerstwo Rolnictwa i Rozwoju Wsi, 2017, Biuletyn Informacyjny 5/2017, Polska wies i rolnictwo 2016 (Polish Rural Areas and Agriculture), Warszawa: p. 14.

6. Polska wies i rolnictwo z lat 2014-2016 (Polish Rural Areas and Agriculture 2014-2016), http://www.minrol.gov.pl/opracowania-ekspertyzy-publikacje (Retrieved on 7 Jan 2018)

7. Sorlin, P.(2001). Mass media. Wroclaw: Wydawnictwo Astrum. p. 11.

8. Sosnowska, J. (2014). Widz spersonalizowany - z problematyki odbioru telewizji tematycznej w Polsce (A personalized viewer - the reception of thematic television in Poland), "Media i spoleczenstwo" 4/2014 Bielsko Biala: Wydawnictwo Naukowe Akademii Techniczno - Humanistycznej w Bielsku - Bialej. pp. 39-41.

9. Szpunar, M. (2014). Internet - nowa sfera publiczna czy kabina poglosowa?( Internet - a new public sphere or a reverberation chamber?).[In:] Media i polityka. Relacje i wspolzaleznosci (Media and politics. Relationships and interdependencies), M. Adamik-Szysiak (Ed.). Lublin: Wydawnictwo Uniwersytetu Marii Curie-Skłodowskiej. Lublin: p. 75.

10. Van Dijk, J. (2010). Spoleczne aspekty nowych mediow. Analiza spoleczenstwa sieci (The Network Society: Social Aspects of New Media ). Warszawa: PWN. pp. 16-19. 